\title{
The Tropical Grey and Black Earths of the Accra Plains, Ghana; their environment, characteristics and air-photograph mapping
}

\author{
F. HAGENZIEKER
}

Formerly Senior Research Officer, University of Ghana

\section{Summary}

Grey solonetzic and black montmorillonitic earths cover extensive areas of the Accra plains in the south-eastern corner of Ghana. Similar soils occur on the Ho-Keta plains east of the river Volta. Both soils are deficient in nitrogen and phosphorus. Mapping may be done from air photographs.

\section{Introduction}

The triangular Accra plains are bounded in the north-west by the Akwapim scarp, by the Guinea coast in the south and by the lower part of the river Volta in the east. The scarp forms the eastern limb of a V-shaped range of hills. This limb runs from a point just north of Accra in a north-easterly direction towards Togoland and Dahomey. The average height above sea level is $1500 \mathrm{ft}$. In the Trans Volta region the hills rise to a maximum altitude of nearly $3000 \mathrm{ft}$. But for the Volta gorge the range is continuous. At Akosombo a high-level dam is under construction to provide hydro-electric power (HaLCROW, 1956). Once the huge artificial lake has been created, its water may become available for irrigation on the Accra plains and on the HoKeta plains, east of the Volta.

The population is nucleated on the periphery of the plains and in the south-eastern corner. Accra has grown into an urban centre surrounded by a 6-mile suburban zone. Shifting cultivation is practised on the sandy loams and sands beneath the Akwapim scarp, on the tertiary sands in the south-east and on levees along the Volta. Coconuts grow on the sandy storm beach. They also occur in small groups near the larger villages as do oilpalms and bananas.

The sparsely populated Grey Earths are not cultivated but these soils provide the major grazing grounds on the plains. West African shorthorn cattle is kept in herds of 100 heads or more on an open range (FIG. 1). Some 200 square miles of Grey Earths cover the Accra plains and another 125 square miles of similar soils occur on the Ho-Keta plains. Considerable improvement of the stock-carrying capacity of the grasslands may be expected from applications of nitrogenous and phosphatic fertilizers (for their effect on Sorghum, see FIG. 2). Furthermore, the construction of small dams to impound drinking water and the production of fodder crops to provide silage for

Received for publication 30th September, 1963.

Neth. J. agric. Sci., Vol. 12 (1964) No. 2 (May) 
supplementary feeding during the dry season has been recommended (HAGENZIEKER, 1961).

The uninhabited Black Earths are neither cropped nor used for grazing. Deficiencies of nitrogen and phosphorus appear to be the main reason for the absence of cultivation (HAGENZIEKER, 1963). The absence of stock might be explained by the unfavourable micro relief of these heavy clays and by the lack of drinking water. Covering a total of approximately 1000 square miles of south-east Ghana, on both the Accra plains and on the Ho-Keta plains the Black Earths extend for some 300 square miles. Their heavy texture necessitates relatively large expenditure on land preparation. Crops to be considered foremost are rice and sugar cane. Local irrigation schemes have been suggested (HuTChINSON and PEARson, 1947; CLARK and Hutchinson, 1948). Large-scale development must be geared to the Volta river project. Investigations on the development and productivity of the Grey and Black Earths have been carried out at the Agricultural Research Station Nungua since 1953. The production of rice and sugar cane on the Black Earths has been taken into study at the Agricultural Research Station Kpong since 1955. Both stations are directed and managed by the Faculty of Agriculture of the University of Ghana.

Besides references quoted, compiled essays in "Agriculture and Land Use" (Wills, editor, 1962) and the "Atlas of the Gold Coast" (Ghana Survey Dept., 1949) may be consulted.

\section{Climate}

Weather and climate of Ghana has been reviewed by WALKer and SwAN (1952) and by WALKer (1957). On the Accra plains annual rainfall totals increase in an easterly direction from 25 to 45 inches. The wettest month is June when more than half of the yearly total may fall. A second, less-developed maximum occurs in October. Though August is relatively dry, the weather is dull and much overcast. Totals for January, the driest month, are generally less than one inch. Variation in rainfall intensity is considerable. Rates of 5 inches per hour may last for short periods.

The mean maximum and minimum temperatures in August vary around $28^{\circ}$ and $21^{\circ} \mathrm{C}$ respectively. In January these modal values are $31^{\circ}$ and $24^{\circ} \mathrm{C}$. During many nights throughout the year dewpoint is reached. Even during the dry season monthly means of daily minimum relative humidities do not drop below $60 \%$. Monthly totals for evaporation from an open water surface vary between 6 inches in January and 4 inches in August.

Daily and seasonal changes in atmospheric conditions are closely associated with movements of the Inter-Tropical Convergence Zone (GARBeLL, 1948), a belt where the moist "monsoon" from the ocean converges with the dry "harmattan" from the desert.

\section{Vegetation}

TAYLOR (1952) refers to the vegetation of the plains as the "Coastal scrub and grassland zone". Further descriptions have been given by Brand and Brammer (1956) and by BRAMMER (1958). The fully-developed scrub may occur on all soils, except the Grey and Black Earths, when it forms an impenetrable thicket of small trees, shrubs and climbers with a closed canopy at a height of 10 to 15 feet above ground level. Grasses and herbs contribute little to this formation. 
FIG. 1. Grey Earths are used by Fulani herdsmen. Scrub on termitaria and on red concretionary soils in background. In foreground coppice shoots on transition of red concretionary soils to Grey Earths

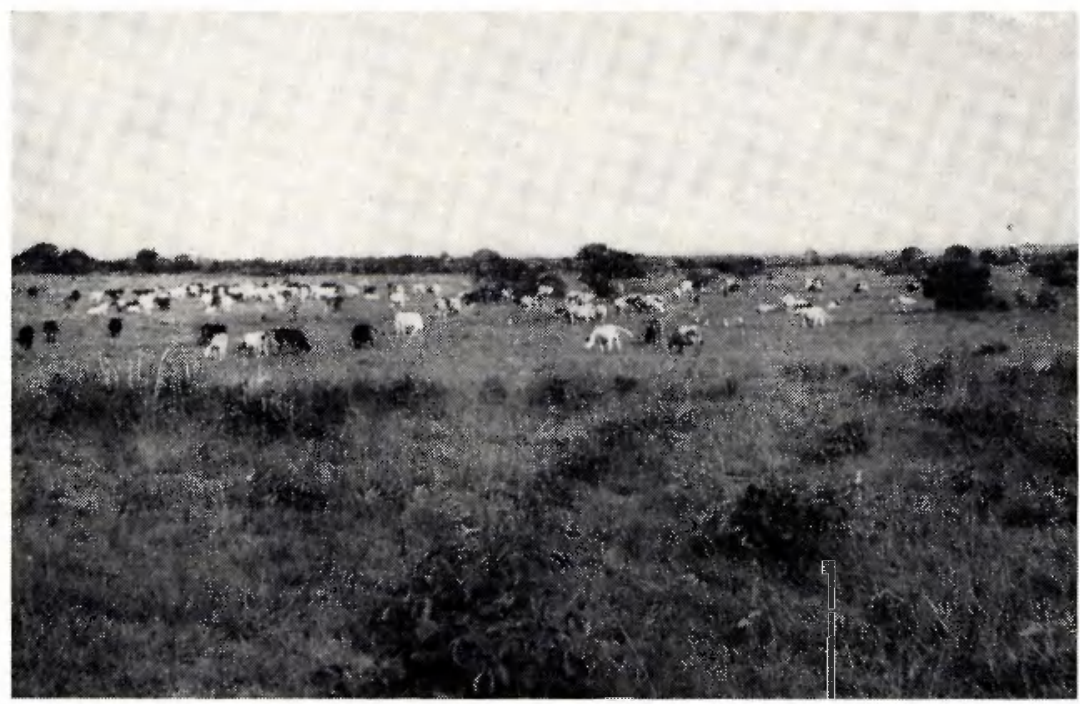

FIG. 2

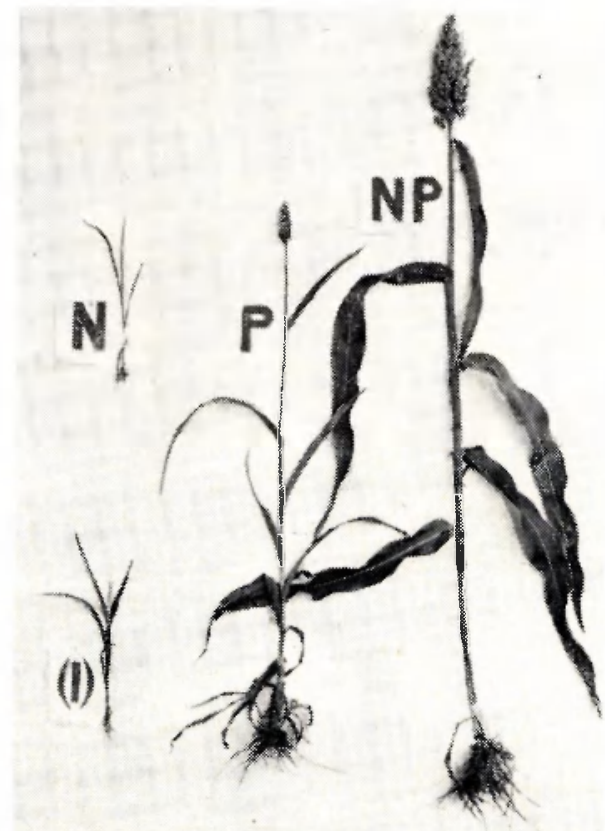

Sorghum showing fertilizer effects on virgin soil:

(I) no fertilizers.

$\mathrm{N}$ a dressing of nitrogenous fertilizers only.

P a dressing of phosphatic fertilizers only.

NP combined dressings of nitrogenous and phosphatic fertilizers. 


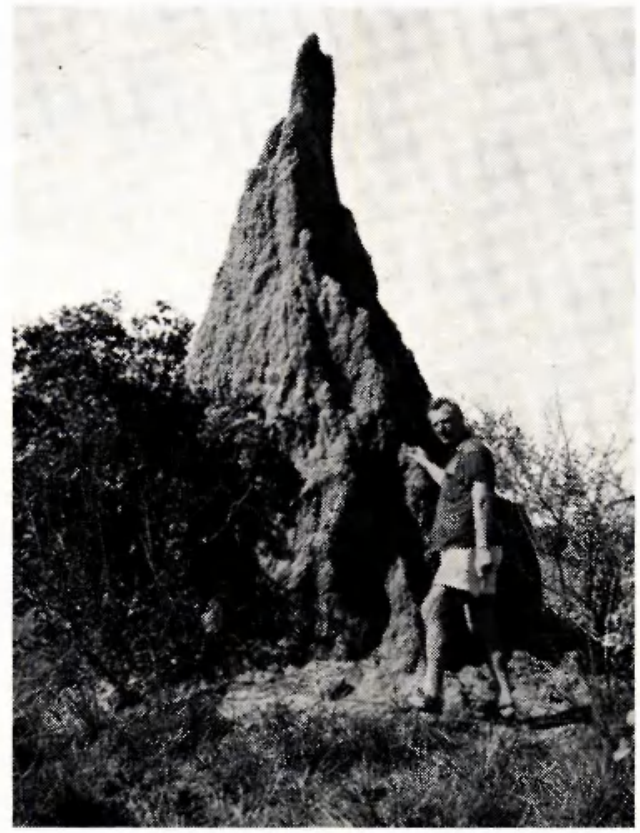

FIG. 3

Active termitarium of the genus Macrotermes with scrub encroaching

FIg. 4. Old termitarium on Grey Earths with coastal scrub. Branches of Eleaphorbia drupifera protruding from main body of scrub

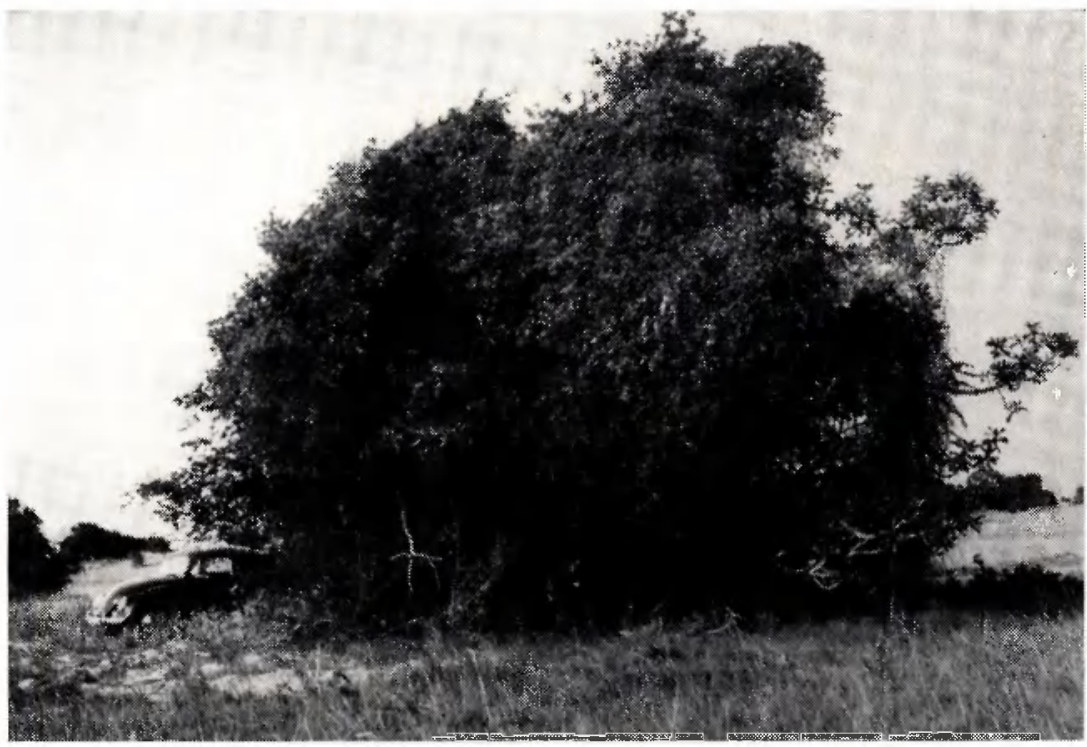


The Grey and Black Earths carry a short grass formation. The height fluctuates around 3 feet and basal cover seldom exceeds $25 \%$. On the Grey Earths species assuming dominance are Veteveria fulvibaris, Andropogon canaliculatis and Schizachyrium spp. Of common occurrence is Ctenium newtonii and in wet places Setaria sphaceleta replaces Veteveria fulvibaris. Almost pure stands of Veteveria fulvibaris are found on the Black Earths. Brachiaria falcifera partly replaces this dominant species on better drained, gravelly variants. Tall grasses of the genera Andropogon, Cymbopogon, Hyparrhenia, Panicum and Pennisetum grow in watercourses and near intermittent streams. Though most conspicuous, these grasses, which are up to 7-feet high, contribute but little to the basal cover.

On the Grey Earths randomly distributed termitaria of the genus Macrotermes (FIG. 3) carry the coastal scrub with Eleaphorbia drupifera as a most conspicuous tree. Many of these anthills are weathered down to dome-shaped mounds some 3 feet high and 15 feet or more in diameter (FIG. 4). They are fringed by pioneer grasses Heteropogon contortus and Sporobulus pyramidalis and by the herbs Abutilon guinense and Crotalaria striata. Kigelia africana (sausage tree) is outstanding in riparian thickets.

On the Black Earths termite activity is limited to the genus Nasutitermes that builds small mounds, one foot in diameter and of the same height. These termitaria are of insufficient extent to provide a foothold for the scrub.

\section{Geomorphology and geology}

With the exception of Akwapim outliers and a number of inselbergs and isolated hills the gently-undulating plains lie below the 250 -foot contour. Through broad and shallow valleys watercourses and intermittent streams drain run-off water to long and narrow lagoons along the coast. Streams running through the Grey Earths dry up to a series of ponds that provide drinking water for cattle during the dry season. No such supplies are found on the Black Earths.

Rocks of pre-cambrian age underlie the plains and compose the adjoining Akwapim range, inselbergs and isolated hills (JUNNER and BATES, 1945; JUNNER, 1946). The upper "Togo series" of the Akwapim range consist of undurated sandstones, quartzites, shists, phyllites and a little limestone. The lower "Dahomeyan series" west of a line from coastal Kpone to inland Kpong on the Volta, comprise predominantly of acidic gneisses, shists and magmatites. East of that line in the region of inselbergs and isolated hills, basic gneisses are found. Granite permeating the acidic gneisses and shists occur in areas of limited extent.

In the south-east corner of the plains an extensive area of tertiary argillaceous sands is found. Adjoining these and further towards the Volta river and along the lagoons are holocene alluvia of unconsolidated gravel, sand and clay. Similar deposits occur in the broad valleys. Along the coast marine beach sands and pebbles are deposited since the pleistocene at different heights to 120 feet above present base level.

Occurring most frequently in the western part of the plains on the summits of flattopped hills at altitudes of 150 to 200 feet are remnants of a late tertiary or pleistocene erosion surface. These remnants may be many feet thick and consist of a ferruginous hardpan into which angular quartz fragments are embedded. BRUECKNER $(1955,1956)$ has given an acceptable explanation for the formation of the cappings (FIG. 5). Postulated were three climatic cycles covering the pleistocene. These cycles have been correlated with the pluvials and interpluvials recognized by BRAMMER $(1958 \mathrm{a}, \mathrm{b})$ in West and others in East and Central Africa and with the glacials and interglacials 
FIG. 5. Schematic representation of the genesis of the mantle rock according to BRUECKNER

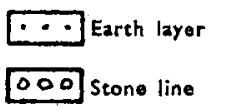

Stages

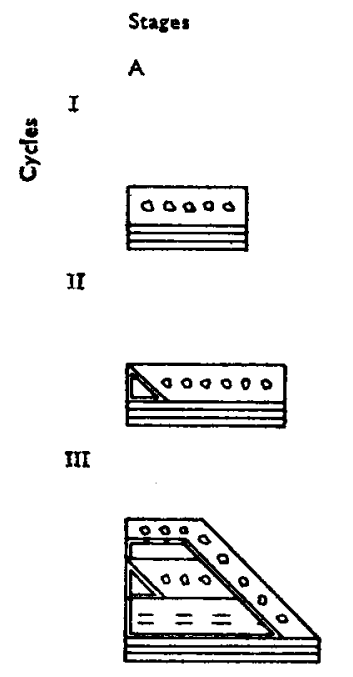

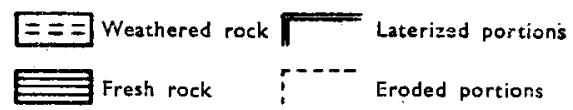

B
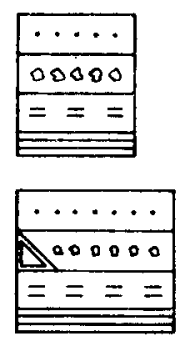

C
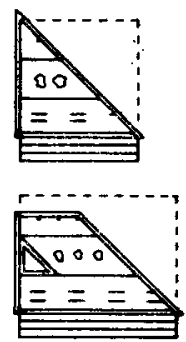

Each of the 3 climatic cycles (I, II, and III) is composed of 3 subsequent stages :

A. An arid period resulting in a desert pavement of coarse material (stonelayer) through physical desintegration and the wind and water removal of finer-grained particles;

B. A warm, humid period affecting the stonelayer and the underlying formations by intensive chemical weathering proceeding downwards, and, at the same time, resulting in the build-up of an earth layer above the remaining line of quartz stones through the activity of soil fauna (predominantly termites);

C. A semi-arid period leading to the complete or partial removal of the earth and underlying stoneline by erosion. This process is simultaneously counteracted by the cementation of these layers through impregnation, predominantly of iron oxides and, to a certain extent, siliceous or aluminous matter.

of higher latitudes. During each cycle an arid period resulted in a desert pavement of rock fragments through physical desintegration and the wind and water removal of finer-grained particles. In a subsequent warm and humid period these fragments were affected by intense chemical weathering proceeding downward while at the same time, resulting from the activity of soil fauna (primarily termites), the remaining line of quartz stones became buried under a layer of fine-grained particles that developed into soil proper. A final semi-arid period in each cycle led to the complete or partial removal of earth and stone line by erosion, which process was simultaneously counteracted by cementation of these layers through impregnation of predominantly ironoxides. Marine erosion resulting from fluctuations in sea level must have contributed greatly to the removal of the lateritic cap with embedded stone lines. 


\section{Soils}

Brammer has carried out a detailed soil survey of the Kpong irrigation area (1954) and a reconnaiscance soil survey of the entire plains (1958). Morphological characteristics of the Tropical Grey and Black Earths have been given by STEPHENS (1953) and by BRAMMER and D'ENDREDY $(1954,1956)$. An agro-pedological evaluation of these soils, including details of soil fertility based on the results of field experiments, has been presented by HAGENZIEKER $(1961,1963)$. In the following description names of soil series used by the Ghana Department of Soil and Land Use Survey are given in brackets.

The Grey Earths are associated with and overlie acid gneisses and shists of the Dahomeyan series. Even over short distances soil profiles differ considerably in composition and depth. In fully-developed profiles of the upper slopes more or less weathered rock is covered by sandy clay on top of which rests loose quartz sand that carries a humic surface horizon (Simpa series). A stone line of subangular quartz is embedded in the base of the clay. In the vicinity of the ferruginous cappings fragments of laterite are also found in the clay. Upon drying, the humic, stained, hard and compact upper layer of the sandy clay cracks into prismatic blocks; when wetted, the horizon turns cloddy and plastic. Further down the sandy clay dries out less hard. Iron mottling may be observed in the contact zone of sand and clay. In the upper slope members of the Grey Earth catena (see FIG. 6) the sand may reach a thickness of 3 to 4 feet whereas the sandy-clay horizon is weakly developed or absent. Downslope the sand horizon becomes thinner while simultaneously the sandy clay increases more rapidly in depth (Agataw series). Near the valley bottom the thickness of the sand horizon is no more than a few inches and the sandy clay reaches down to 12 feet or more before hitting rock. The stone line appears less developed in the lower members of the catena. Dolomitic and partly silicified carbonate concretions appear half way down the slope in the sandy clay and are most prevalent in the valley-bottom soils. The sandy clay is virtually impervious. Excessive rain saturates the sand resulting in early run-off and lateral drainage immediately above the sandy-clay horizon. More prolonged lateral movement of water takes place through the stone line. The sand is subject to severe water erosion. The solonetzic profile morphology indicates the presence of highly dispersible sodium clay and humus. This conclusion is confirmed by the results of soil analyses. The presence of sodium is satisfactorily explained by the occurrence of plagioclase in the parent rock. Chlorides, occurring in the lower layers of the sandy clay, are thought to be derived from fossil sea water held in the rocks since quarternary marine invasions. The stone line is made up of fragments from quartz veins in the parent rock and of eroded remnants of the lateritic cappings with embedded pieces of quartz.

The Black Earths (Akuse series) overlie and have been derived from basic gneisses. The surface of these heavy-textured soils shows distinct forms of micro relief, known as "gilgai" in Australia (HAllsworth et al., 1955). Conditions necessary for the formation of "gilgai relief" are: a. alternate wet and dry seasons, b. montmorillonitic clay and c. an increase with depth in the amount of adsorbed sodium. These criteria are complied with on the Accra plains. During dry seasons cracks develop that widen with depth. Secondary cracks cause the surface soil to disintegrate into small fragments that fall to the bottoms of the main cracks into which also runs most of the early rain water. The resultant swelling of the fragmented soil leads to the fracture of soil blocks that are forced upwards above the original surface. Subsequent drying 
FIG. 6. The Grey Earths catena

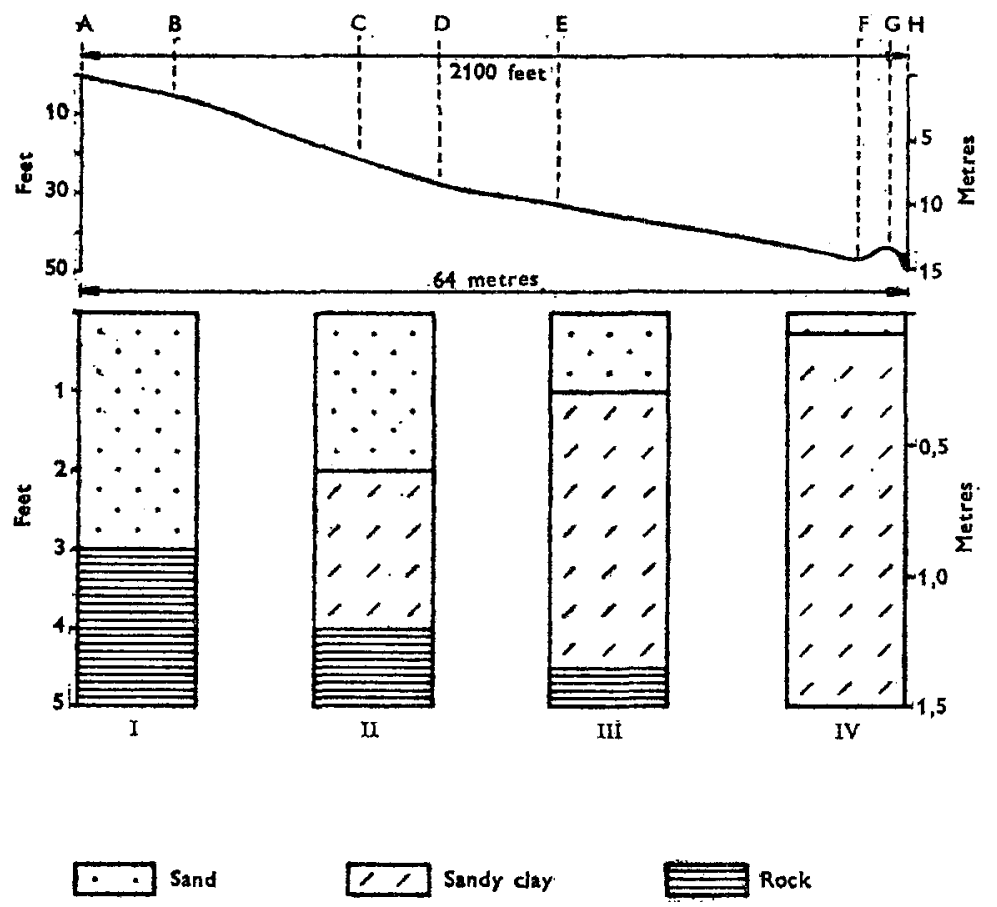

I from $A$ to $B$ : Simpa series on or near the summits.

II "B "C : Agawtaw series of the upper slopes.

III " C " E : Agawtaw series of the middle slopes.

IV " E "F : Agawtaw series of the lower slopes and valley bottoms.

at D : Break of slope which may result in a wet zone.

"G : Sandy levee.

" H: Seasonal stream drying up to a series of ponds fed by lateral seepage over the impervious horizon of sandy sodium clay.

Over extensive areas of flat or slightly-rolling country the effects of topography cannot be recognized. Simpa and Agawtaw series occur side by side, forming an intricate pattern.

and wetting results in a repetition of the process as primary cracks tend to be formed along the same planes of weakness. Erosion of the "puffs" raised above the surrounding "shelves" establishes a dynamically equilibrated form of microrelief whereby the solum is turned over gradually. Parts of the "puffs" that are orientated across the lines of slope are most easily eroded, while those parallel to the contours tend to be preserved. This leads to the formation of gentle undulations arranged in regular patterns up and down slopes. Where "puffs" and "shelves" are continuous the name "wavy gilgai" is used. The term "lattice gilgai" refers to patterns of continuous "shelves" and discontinuous "puffs" arranged in oblong strips along the contours.

Both forms may be observed on the Accra plains, particularly in the more drier parts. They are distinguished most easily at the onset of the prime rainy season on land that had been burned. After the first showers the young grass flushes on the 
FIG. 7. Airphoto No. 9229

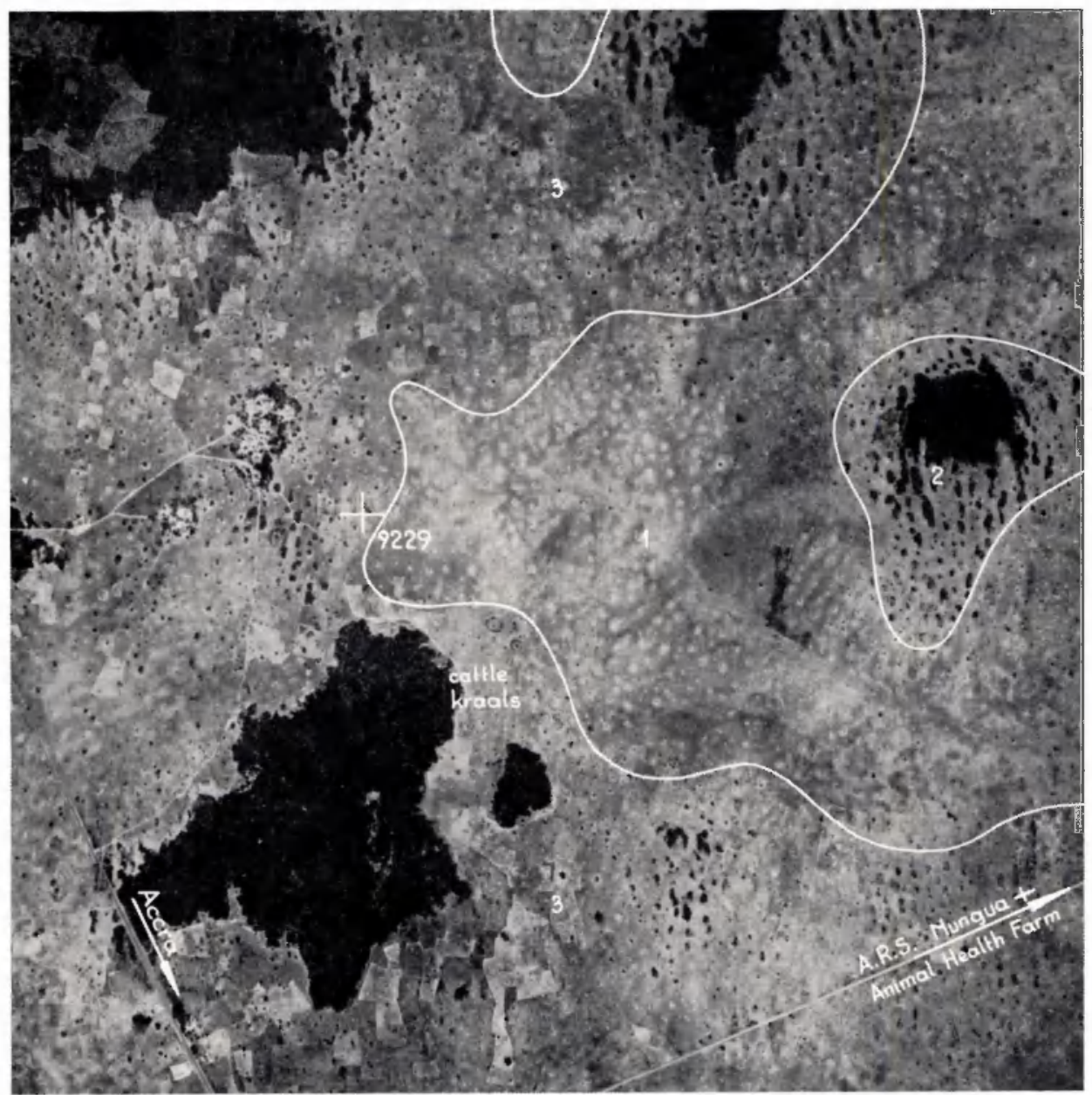

1: Grey Earths with watercourse; termitaria deprived of scrub show as light-coloured dots.

2: Red concretionary soils with fully-regenerated and fire-aligned coastal scrub.

3: Red sandy loams devloped over colluvia of the Akwapim scarp with red concretionary soils on scrub-covered summits of elevations. Cultivations predominantly on the sandy loams. 
FIG. 8. Airphoto No. 9235

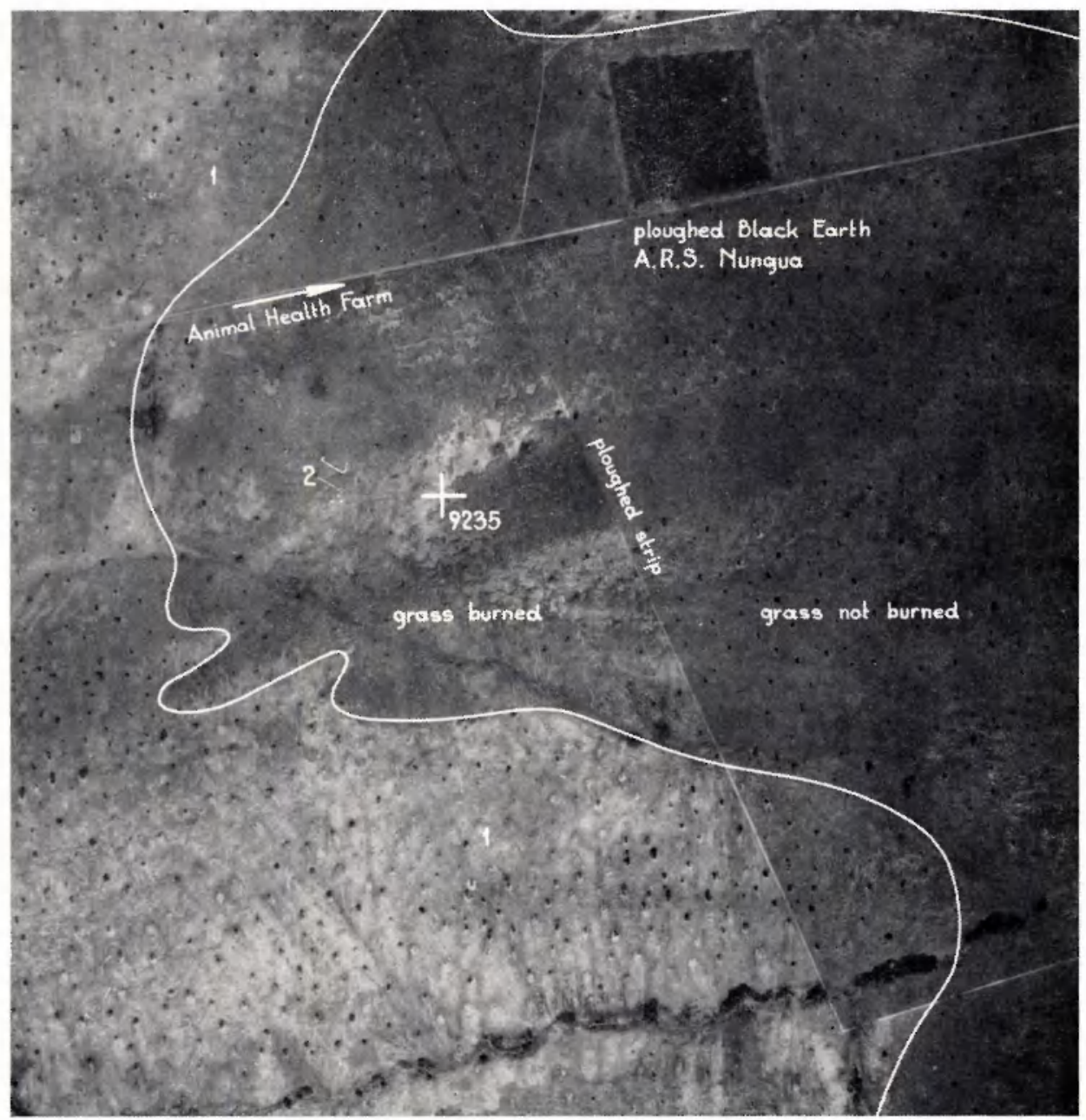

1: Grey Earths. Streaky surface features caused by run-off to seasonal stream are most distinctive on burned land. Termitaria with scrub show as dark dots fringed by a light-coloured band indicating bare soil. Scrub also grows on sandy levees.

2: Black Earths. The occurrence of scrub clusters showing as dark dots on this photograph is not representative, most of the Black Earths of the continuous belt from coastal Kpone to Kpong on the Volta river only carrying grass. Gilgai micro relief is clearly visible on burned land. 
FIG. 9. Airphoto No. 9239

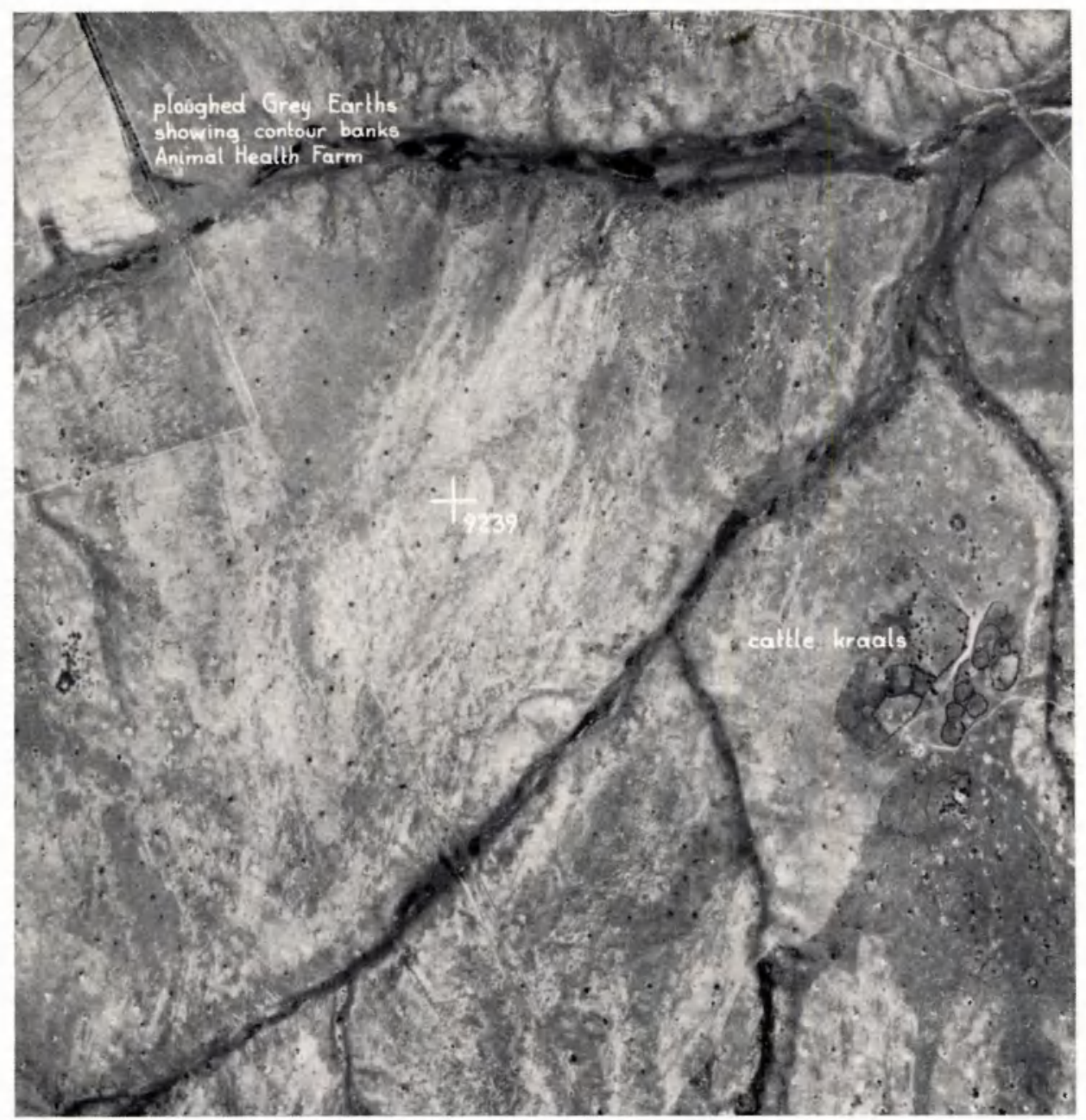

Confluence of seasonal streams in Grey Earths area with recent alluvia. Gilgai micro relief in places at lower ends of slopes. 
"puffs" before any growth on the "shelves" occurs. This results in a short, lived pattern of alternating green and dark strips. Profile characteristics are uniform over large areas. "Puffs" show a 4- to 6-inch surface horizon bf black plastic clay that disintegrates into hard clods and nuts on drying and containing most of the grass roots. The horizon is less pronounced on "shelves". Underneath lies a black heavy clay that is plastic and impervious when moist and cracks into vertical columns of irregular shape on drying. This horizon usually varies between 3 and 6 feet but it may be less than 12 inches. Grass roots are sparse. The succeeding horizon is distinguished by an abundance of carbonate concretions and the absence of cracks. At the base, the concretions may be sufficiently numerous to produce a greyish-white soil colour. The horizon varies in thickness from one to 3 feet and is distinctly more friable than the overlying clay. The distinction between the two horizons is ill-defined and shows wavy deformations. A well-developed, non-cracking "puff" shows carbonate concretions throughout the profile; their numbers increase with depth. A stone line of quartz fragments, if present, separates the solum from solid or weathered bedrock. Near ironstone cappings, fragments of laterite may be present in the stone line. The depth of the weathering zone varies with the mineralogical composition and structure of the bedrock. Where shistose material with an abundance of biotite occurs, the weathered zone of brownish plastic material may be a few feet in thickness. Elsewhere, the clay overlies fresh pyroxenite gneiss. The dark-grey to black soil colour appears to be associated with a particular form of organic matter that may be reproduced in vitro under alkaline and anaerobic conditions (Hessyan and Hurton, 1954). A brown variant of the Black Earths is indicative for better internal drainage (Ashaiman series).

Peneplain remnants of quartz fragments and massive ironstone in a matrix of clay are overlain by a few inches of red sandy loam at the summits (Nyigbenya series). The cappings may be many feet thick. Downslope the lateritic layer thins out and eventually becomes fragmented while simultaneously the thickness of the loamy overburden increases.

Red sandy loams are derived from colluvia along the Akwapim escarpment. Generally the clay content increases down the profile and stone lines of quartz fragments occur at depths of some 4 feet or more.

Alluvial valley soils form a geographically associated complex. In places, weakly developed sandy levees occur along intermittent streams that drain the Grey Earths. Soils of drainage channels largely assume characteristics identical to those of the associated Grey and Black Earths.

\section{Interpretation of air photographs}

Aerial surveys of the Accra plains were made by the Air Force during the war. Most of the photographs taken lack sufficient quality for a clear interpretation. In February 1954 the Agricultural Research Station Nungua and the 25-square mile catchment area of a dam built on the station were photographed by the Aircraft Operating Company of Africa, an associated company of the Hunting Group. The camera used was a Wild R.C. 5 with an Aviogon lens of $11,45 \mathrm{~cm}$ focal length. Overlap in the direction of flight was $60 \%$ and between the 4 runs $30 \%$. The pictures were taken on panchromatic film at a scale of approximately $1: 15.000$. Interpretation may be done without the need of stereoscopic observation. For this reason and in order to cover a relatively extensive area with a minimum number of prints, 3 photographs that do not overlap are reproduced in part (FIGS. 7, 8, 9). 
The pictures cover stretches of the area along the road leading from the village Nkwantanang to the Agricultural Research Station Nungua and the adjoining Animal Health Farm.

The Grey Earths may be recognized by their light image, the occurrence of randomly spaced termitaria and the streaky appearance reflecting surface wash towards the nearest drainage channels. Most of the termitaria carry scrub and show up as dark dots. Where the scrub has been cleared, the bare soil of the anthills produces a white imaged dot.

The dark colour of the Black Earths is reflected on the photographs and the gilgai micro relief is discernible on freshly burnt land in particular.

Red concretionary soils are distinguished by their cover of coastal scrub, either continuous or in elongated strips. The last form occurs where after clearing the scrub becomes reestablished. During the dry season, grass fires sweep over the plains and these cause the scrub to be fire-aligned in a S.W. to N.E. direction, parallel to the prevailing wind. The transition of red concretionary soils to sandy loams developed over colluvia of the Akwapim scarp is ill-defined.

Though detailed soil maps cannot be compiled without an intensive ground survey, it is clear that aerial photographs offer the possibility of recognizing the principal groups of soils and other features of importance for large-scale agricultural planning.

\section{ACKNOWLEDGEMENTS}

Thanks are due to Messrs. Aircraft Operating Company (Aerial Surveys) Ltd., P.O. Box 2830, Johannesburg, South Africa, for their permission to publish the air photographs and to Prof. J. F. V. PHILliPs for his stimulating encouragement.

Brammer, H.

\section{$\longrightarrow$, and A. S.}

BRAMMER, H., and

A. S. DE ENDREDY

BRAND, B., and $\mathrm{H}$.

BRAMMER

BRUECKNER, W.

Clark, W. M., and F. H. HUTCHINSON

Garbell, M. A.

\section{REFERENCES}

1955 Detailed soil survey of the Kpong pilot irrigation area. Ghana Dept. of Soil and Land Use Survey (S.L.U.S.).

1958a Report on the reconnaissance soil survey of the Accra plains. Ghana Dept. S.L.U.S.

1958b Vegetation studies on the Accra plains. Ghana Dept. S.L.U.S.

1954 The Tropical Black Earths of the Gold Coast and their associated Vlei soils. Proc. Vth Intern. Congr. Soil Sci., Leopoldville, 1954, IV , 70-76.

1956 The Tropical Grey Earths of the Accra plains, Gold Coast. Proc. Intern. Congr. Soil Sci., Paris, 1956.

1956 Provisional grassland associations of the interior and coastal savannah zones of the Gold Coast. Ghana Dept. S.L.U.S.

1955 The mantle rock (laterite) of the Gold Coast and its origin. Geol. Rundschau. B. 43, Heft 2, 307-327.

1956a On structural irregularities in the mantle rock of the Gold Coast. Journ. W. Afric. Sci. Assoc. 2, 1: 87-97.

1956b Laterite and bauxite profiles of West Africa as an index to rythmical climatic variations in the tropical belt. Proc. Intern. Geol. Congr., Mexico City, 1956.

1948 British West African rice missions report on the possibility of expanding the production of rice in the British West African Colonies. Report to the Secretary of State for the Colonies, London.

1948 Tropical and equatorial meteorology. 
Ghana Survey Dept.

HAgENZIEKer, F.

\section{HALCROW, SiR WILliam} et al.

HALlSWORTh, E. G., J. K. ROBERTSON and F. R. GibBons

Hessyan, D. G., and G. R. Hutton

Hutchinson, J. B., and E. O. Pearson

JUNNER, N. R.

- and D. A. BATES

\section{Stephens, I.}

TAYLOR, C. J.

WALKER, H. O. and A. D. Swan Wills, J. B. (editor)
1949 Atlas of the Gold Coast.

1955 Geological map of the Gold Coast and Togoland under British trusteeship.

1961 Contribution to the agropedological knowledge of the solonetzic Tropical Grey Earths of the Accra plains, Ghana. Neth. J. agric. Sci. 9, 249-261.

1963 Contribution to the agropedological knowledge of the Tropical Black Earths of southern Ghana. Neth. J. agric. Sci. 11, $54-65$.

1956 The Volta River Project.

1955 Studies in pedogenesis of New South Wales. III. The gilgai soils. Journ. Soil Sci. 6, 1-31.

1954 In vitro production of Tropical Black Earth. Nature. 177, 612.

1947 Report on a visit to the Gold Coast. Report to the Empire Coton Growing Assoc., London.

1946 Progress in geological and mineralogical investigations in the Gold Coast. Survey Dept., Accra.

1945 Report on the geology and hydrology of the coastal area east of the Akwapim Range. Survey Dept., Accra.

1953 A petrographic study of a Tropical Black Earth and Grey Earth from the Gold Coast. Journ. Soil Sci. 4, 2: 211-219.

1952 The vegetation zones of the Gold Coast. Gold Coast Forestry Dept., Accra, Bull. No. 4.

1957 Weather and climate of Ghana. Ghana Meteor. Dept., Accra. Note No. 4.

1952 The climatology of Ghana. Ghana Meteor. Dept., Accra.

1962 Agriculture and land use in Ghana. 